\title{
Analysis of genetic diversity and population structure in Argentine and Bolivian Creole cattle using five loci related to milk production
}

\author{
J.P. Lirón, M.V. Ripoli, J.C. De Luca, P. Peral-García and G. Giovambattista \\ Centro de Investigaciones en Genética Básica y Aplicada (CIGEBA). Facultad de Ciencias Veterinarias, \\ Universidad Nacional de La Plata, La Plata, Argentina.
}

\begin{abstract}
Data from five protein-coding loci related to dairy production were used to study the genetic diversity and population structure of Argentine and Bolivian Creole cattle breeds. Genomic DNA was extracted from blood samples of six Creole cattle breeds: Argentine $(n=230)$, Patagonian $(n=25)$; "Saavedreño" $(n=140)$, "Chaqueño Boliviano" ( $n=$ $30)$, "Yacumeño" $(n=27)$, and "Chusco" $(n=11)$. $\kappa$-casein, $\beta$-lactoglobulin, growth hormone and prolactin were measured by PCR-RFLP, while $\alpha_{S 1}$-casein was typed by PCR-ASO. The results are discussed, focusing on: historical origin, recent differentiation and selection events, Zebu gene introgression, and population structure. This work shows that: (i) For the studied genes, the observed gene frequency profiles of Argentine and Bolivian Creole cattle breeds were close to the data reported for Iberian breeds and for other South-American Creole cattle breeds which are historically related; (ii) although Zebu gene introgression has been reported at the studied loci, these breeds seem to be far from the Zebu gene frequency profiles; and (iii) the Argentine and Bolivian Creole cattle showed significant levels of subdivision, but each population has maintained its degree of genetic variability.
\end{abstract}

Key words: Creole cattle, polymorphism, genetic diversity, molecular markers.

Received: July 26, 2002; accepted: October 28, 2002.

\section{Introduction}

\section{American Creole cattle}

Anthropological and paleontological evidence shows that the first cattle were brought to America by Spanish conquerors starting in 1493 (Primo, 1992). The founder populations of Creole cattle, introduced in America by the Spanish and Portuguese conquerors during the first 50 years of colonization, consisted of 300 to 1000 animals of Iberian origin (Primo, 1992; Wilkins et al., 1982). In the course of a few years, these animals were taken to Central and South America, and to the South of the current United States, spreading from there over the South-American continent. The Creole cattle were the only bovines bred in Latin America for more than 300 years, until selected European and Zebu breeds were introduced.

American Creole cattle evolved under low levels of breeding management and, as a result of natural selection, became adapted to different environments, such as the tropical rainforest, the subtropical dry forest, the highland

Send correspondence to G. Giovambattista, Centro de Investigaciones en Genética Básica y Aplicada (CIGEBA). Facultad de Ciencias Veterinarias, Universidad Nacional de La Plata, 60 y 118 s/n. CC 296 (B1900AVW) La Plata, Argentina. E-mail: ggiovam@ fcv.unlp.edu.ar. steppe, and the Patagonian steppe. Furthermore, American Creole cattle exhibit a high degree of phenotypic variability (e.g., coat color), resistance to tropical diseases, and high levels of fertility.

Nowadays, there are Creole cattle breeds in almost all American countries (http://www.ansi.okstate.edu/breeds/ cattle/). In Bolivia, four different Creole cattle breeds can be recognized: (i) Yacumeño Creole cattle, a breed adapted to the seasonal flood plain of the northern region of Bolivia (Department of El Beni), currently amounting to approximately 1200 animals, raised primarily for beef; (ii) Bolivian Chaqueño Creole cattle, a breed of about 1200 animals, raised for beef, found in the south-eastern area of Bolivia, in a dry forest environment, mainly located at the Experimental Station "del Chaco El Salvador" (Department of Chuquisaca, besides small herds on private farms of the "Chaqueño" region (Departments of Chuquisaca and Santa Cruz); (iii) Chusco Creole cattle, adapted to the highland plain of western Bolivia (Department of La Paz), raised for beef, and with a population of approximately 200,000 animals; (iv) Saavedreño Creole cattle, mainly found at the "Saavedra" Experimental Station (Department of Santa Cruz), with a population of approximately 300 adults, raised for dairy and beef, on a tropical plain. 
In Argentina, a single Creole cattle breed can be recognized, including two different types: (i) Argentine Creole cattle, with a broad geographical distribution (from the Pampa region in the South to the subtropical region in the North), adapted to a wide range of environments, the most numerous relict, about 200,000 heads, living in the subtropical region (north-western Argentine); and (ii) Patagonian type of Argentine Creole cattle descending from the bovines introduced from the end of $18^{\text {th }}$ century up to the beginning of the $20^{\text {th }}$ century in the region going from the Pampa to Patagonia. Nowadays, the only pure group remains isolated in Los Glaciares National Park (south-western Patagonia) and is adapted to the Andean Cold Forest. Both types are raised for beef.

\section{Studies of genetic polymorphism in cattle}

Between the decades of the 1960 and 1980, phylogenetic and population genetic studies in domestic animals were carried out by analyzing their blood group and protein polymorphisms (Baker and Manwell, 1980; Manwell and Baker, 1980). In the 1990s, the classic methodologies were replaced by microsatellite techniques, because this kind of markers present advantages over blood group and biochemical polymorphisms. They appear to be abundant, evenly distributed throughout the genome, and they display a high degree of polymorphism. Therefore, microsatellites are currently the commonest markers used for genetic characterization of livestock species (MacHugh et al., 1994, 1997; Moazami-Goudarzi et al., 1997; Loftus et al., 1999; Kantanen et al., 2000).

To date, several class I polymorphisms have been reported in different bovine breeds, but in many cases their status (gene frequencies, gene diversity, differences between breeds) is still unknown.

This paper outlines the results of an analysis of the genetic diversity and population structure of Argentine and Bolivian Creole cattle breeds, using data from five protein-encoding loci related to dairy production. This report provides data which allow to analyze the level and range of genetic variability within and between these cattle breeds, and to compare them with data reported in European and Zebu breeds. The results are expected to be useful in designing management plans for these populations.

\section{Materials and Methods}

Blood samples of unrelated animals were collected, with ACD (6:1) as anticoagulant, from the following Creole cattle breeds: Argentine $(\mathrm{n}=230)$, Patagonian $(\mathrm{n}=$ 25); "Saavedreño" $(\mathrm{n}=140)$, "Chaqueño Boliviano" ( $\mathrm{n}=$ 30), "Yacumeño" $(\mathrm{n}=27)$, and "Chusco" $(\mathrm{n}=11)$. The Argentine Creole cattle samples were obtained from eight different populations located along their geographical distribution. Genomic DNA was isolated from white blood cells, using DNAzol ${ }^{\mathrm{TM}}$ (Gibco Brl, Life Technologies, N.Y., USA).
DNA samples were typed for five genetic markers. Tests for $\kappa$-casein $(\kappa$-cas), $\beta$-lactoglobulin $(\beta$-lg), and growth hormone $(G H)$ genes were performed by PCRRFLP, according to the procedures proposed by Agrawala et al. (1992), Medrano and Aguilar-Córdoba (1990), and Yao et al. (1996), respectively. $\alpha_{S 1}$-casein $\left(\alpha_{S 1}\right.$-cas $)$ was typed by PCR-ASO (allele-specific oligonucleotide), as described by David and Deutch (1992). Prolactin (PRL) primers previously reported by Lewin et al. (1992) were included in the PCR reaction as positive controls for DNA amplification. Furthermore, an aliquot of PCR product was digested with $R s a$ I restriction enzyme, in order to genotype the $P R L$ allelic variants. The restriction fragments of each genetic system were discriminated by running them in $6 \%$ (19:1) polyacrylamide minigels in $1 \mathrm{x}$ TBE ( $170 \mathrm{v}, 45 \mathrm{~min})$, stained with ethidium bromide, and visualized under UV light.

Gene and genotype frequencies for each analyzed locus in the breeds studied were determined by direct counting, and their standard errors were computed as the square root of the variance of a binomial distribution. HardyWeinberg equilibrium (HWE) for each locus within populations was estimated by $F_{I S}$ statistics (Weir and Cockerham, 1984), using the exact test of the HWE GENEPOP software (Gou and Thompson, 1992; Raymond and Rousset, 1995). The genetic variability was evaluated through the observed number of alleles $\left(\mathrm{n}_{\mathrm{a}}\right)$, the unbiased expected heterozygosity $\left(h_{\mathrm{e}}\right)$ for each locus, and the average heterozygosity over all loci $\left(\mathrm{H}_{\mathrm{e}}\right)$. These parameters were calculated according to Nei (1987), using the ARLEQUIN 2.0 software package (Schneider et al., 2000) The degree of genetic variation between all breed pairs, measured by the parameter $\mathrm{H}_{\mathrm{e}}$, was compared using Student's $t$ test, as described by Nei (1987).

The $\mathrm{F}_{\mathrm{ST}}$ index and the pairwise $\mathrm{F}_{\mathrm{ST}}$ were used as estimators of genetic subdivision and genetic differentiation among the Creole cattle breeds studied. This parameter was calculated using the GENEPOP software package (Raymond and Rousset, 1995).

\section{Results}

Gene frequencies and their standard errors for each locus of the six Creole cattle breeds studied are given in tables 1 to 5. The techniques used for the typing of the $\kappa-c a s$, $\alpha_{S 1}$-cas, $\beta$-lg, $G H$, and PRL loci (Medrano and AguilarCórdoba, 1990; Agrawala et al., 1992; David and Deutch, 1992; Lewin et al., 1992; Yao et al., 1996) allowed us to detect two variants for each locus. All analyzed genes showed to be polymorphic, with the exception of $G H$ and $P R L$ in the Patagonian and Yacumeño Creole cattle, respectively (Tables 4 and 5).

The values of unbiased expected heterozygosity $\left(h_{\mathrm{e}}\right)$ for each locus of the six breeds, calculated from gene frequencies, are given in tables 1 to 5 . In the polymorphic loci, 
Table I - Number of detected alleles ( $\mathrm{n}_{\mathrm{a}}$ ), gene frequencies, unbiased expected heterozygosity $\left(\mathrm{h}_{\mathrm{e}}\right)$ and its standard errors (SD), and $\mathrm{F}_{\text {IS }}$ index estimated for K-casein locus in Argentine Creole (ACc), Patagonian Creole ( $\mathrm{PaCc}$ ), Saavedreño ( $\mathrm{SaCc}$ ), Chaqueño Boliviano (ChBCc), Yacumeño (YaCc), and Chusco $(\mathrm{ChuCc})$ cattle breeds.

\begin{tabular}{lcccccc}
\hline Breed & $\mathrm{n}_{\mathrm{a}}$ & \multicolumn{3}{c}{ Allele frequencies } & \multirow{2}{*}{$\mathrm{h}_{\mathrm{e}} \mathrm{SD}$} & $\mathrm{F}_{\text {IS }} \mathrm{p}$ value \\
\cline { 3 - 5 } & & $\mathrm{A}$ & $\mathrm{B}$ & $\mathrm{SD}$ & & \\
\hline $\mathrm{ACc}^{1}$ & 2 & 0.609 & 0.391 & 0.000 & $0.477 \pm 0.010$ & $15.5 ; 0.486^{2}$ \\
$\mathrm{PaCc}$ & 2 & 0.605 & 0.395 & 0.079 & $0.491 \pm 0.126$ & $0.036 ; 1.000$ \\
$\mathrm{SaCc}$ & 2 & 0.560 & 0.440 & 0.000 & $0.494 \pm 0.006$ & $-0.124 ; 0.106$ \\
$\mathrm{ChBCc}$ & 2 & 0.355 & 0.645 & 0.000 & $0.465 \pm 0.037$ & $0.030 ; 1.000$ \\
$\mathrm{YaCc}$ & 2 & 0.426 & 0.574 & 0.000 & $0.498 \pm 0.024$ & $-0.270 ; 0.240$ \\
$\mathrm{ChuCc}$ & 2 & 0.700 & 0.300 & 0.000 & $0.442 \pm 0.087$ & $0.100 ; 1.000$ \\
\hline
\end{tabular}

${ }^{1}$ Corresponding to an average of 8 ACc populations; ${ }^{2}$ Estimated by Fisher's exact test.

Table II - Number of detected alleles $\left(\mathrm{n}_{\mathrm{a}}\right)$, gene frequencies, unbiased expected heterozygosity $\left(\mathrm{h}_{\mathrm{e}}\right)$ and its standard errors (SD), and $\mathrm{F}_{\text {IS }}$ index estimated

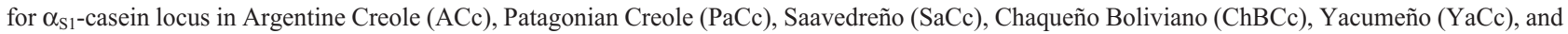
Chusco (ChuCc) cattle breeds.

\begin{tabular}{lcccccc}
\hline Breed & $\mathrm{n}_{\mathrm{a}}$ & \multicolumn{3}{c}{ Allele frequency } & \multirow{2}{*}{$\mathrm{h}_{\mathrm{e}}-\mathrm{SD}$} & $\mathrm{F}_{\text {IS }}-\mathrm{p}$ value \\
\cline { 3 - 5 } & & $\mathrm{B}$ & $\mathrm{C}$ & $\mathrm{SD}$ & & \\
\hline $\mathrm{ACc}^{1}$ & 2 & 0.653 & 0.347 & 0.000 & $0.425 \pm 0.020$ & $15.6 ; 0.480^{2}$ \\
$\mathrm{PACc}$ & 2 & 0.917 & 0.083 & 0.000 & $0.157 \pm 0.077$ & $-0.036 ; 1.000$ \\
$\mathrm{SaCc}$ & 2 & 0.843 & 0.157 & 0.000 & $0.266 \pm 0.025$ & $-0.068 ; 0.277$ \\
$\mathrm{ChBCc}$ & 2 & 0.787 & 0.212 & 0.000 & $0.339 \pm 0.053$ & $0.114 ; 0.656$ \\
$\mathrm{YaCc}$ & 2 & 0.944 & 0.056 & 0.000 & $0.107 \pm 0.055$ & $-0.040 ; 1.000$ \\
$\mathrm{ChuCc}$ & 2 & 0.889 & 0.111 & 0.000 & $0.209 \pm 0.116$ & $-0.067 ; 1.000$ \\
\hline
\end{tabular}

${ }^{1}$ Corresponding to an average of 8 ACc populations; ${ }^{2}$ Estimated by Fisher's exact test.

Table III - Number of detected alleles $\left(\mathrm{n}_{\mathrm{a}}\right)$, gene frequencies, unbiased expected heterozygosity $\left(\mathrm{h}_{\mathrm{e}}\right)$ and its standard errors (SD), and $\mathrm{F}_{\text {IS }}$ index estimated for ß-lactoglobulin locus in Argentine Creole ( $\mathrm{ACc}$ ), Patagonian Creole ( $\mathrm{PaCc}$ ), Saavedreño ( $\mathrm{SaCc}$ ), Chaqueño Boliviano ( $\mathrm{ChBCc}$ ), Yacumeño ( $\mathrm{YaCc}$ ), and Chusco (ChuCc) cattle breeds.

\begin{tabular}{lcccccc}
\hline \multirow{2}{*}{ Breed } & $\mathrm{n}_{\mathrm{a}}$ & \multicolumn{3}{c}{ Allele frequency } & \multirow{2}{*}{$\mathrm{h}_{\mathrm{e}} \pm \mathrm{SD}$} & \multirow{2}{*}{$\mathrm{F}_{\text {IS }}$ - $\mathrm{p}$ value } \\
\cline { 3 - 5 } & & $\mathrm{A}$ & $\mathrm{B}$ & $\mathrm{SD}$ & & \\
\hline $\mathrm{ACc}^{1}$ & 2 & 0.346 & 0.654 & 0.054 & $0.458 \pm 0.034$ & $1.000 ; 0.915^{2}$ \\
$\mathrm{PACc}$ & 2 & 0.845 & 0.155 & 0.047 & $0.267 \pm 0.047$ & $0.044 ; 0.563$ \\
$\mathrm{SaCc}$ & 2 & 0.175 & 0.825 & 0.023 & $0.290 \pm 0.030$ & $0.224 ; 0.265$ \\
$\mathrm{ChBCc}$ & 2 & 0.397 & 0.603 & 0.065 & $0.487 \pm 0.029$ & $-0.118 ; 0.714$ \\
$\mathrm{YaCc}$ & 2 & 0.483 & 0.517 & 0.065 & $0.508 \pm 0.013$ & $0.617 ; 0.082$ \\
$\mathrm{ChuCc}$ & 2 & 0.400 & 0.600 & 0.112 & $0.505 \pm 0.056$ & $0.617 ; 0.082$ \\
\hline
\end{tabular}

${ }^{1}$ Corresponding to an average of 8 ACc populations; ${ }^{2}$ Estimated by Fisher's exact test.

the $\mathrm{h}_{\mathrm{e}}$ ranged from $0.034 \pm 0.033$ for $P R L$ in the "Chaqueño Boliviano" populations to $0.508 \pm 0.056$ for $\beta$ - $\lg$ in the Yacumeño breed. The average heterozygosity $\left(\mathrm{H}_{\mathrm{e}}\right)$ was also estimated for each population, varying from 0.202 in the Patagonian Creole to 0.356 in the Argentinean Creole breed $\left(\mathrm{H}_{\mathrm{e}}\right.$, Argentinean Creole $=0.356 ; \mathrm{H}_{\mathrm{e}}$, Patagonian $=0.202 ; \mathrm{H}_{\mathrm{e}}$, Saavedreño $=0.342 ; \mathrm{H}_{\mathrm{e}}$, Chaqueño Boliviano $=0.315 ; \mathrm{H}_{\mathrm{e}}$, Yacumeño $=$ 0.308 , and $\mathrm{H}_{\mathrm{e}}$, Chusco $=0.300$ ). However, there was no signif- icant difference between the obtained $\mathrm{H}_{\mathrm{e}}$ values of the studied breeds $(\mathrm{t}<1.638 ; \mathrm{p}>0.10)$.

The $\mathrm{F}_{\text {IS }}$ showed that the observed genotype frequencies presented no significant deviations from the predicted HWE at each locus of the six breeds studied, except for $G H$. Furthermore, when HWE were considered per locus across populations and per breed over all loci, all populations were in equilibrium ( $p>0.642$, and $p>0.067$, respectively). 
The $\mathrm{F}_{\mathrm{ST}}$ index and the exact test for population differentiation were used to analyze the degree of genetic differentiation among the Creole cattle breeds studied. Parameter $\mathrm{F}_{\mathrm{ST}}$ showed significant differences across Creole cattle populations $\left(\mathrm{F}_{\mathrm{ST}}=0.115\right)$, ranging from 0.030 to 0.267 for each locus $\left(\mathrm{F}_{\mathrm{ST}} \mathrm{\kappa}_{\text {-cas }}=0.061 ; \mathrm{F}_{\mathrm{ST}} \alpha_{\text {S1-cas }}=0.107 ; \mathrm{F}_{\mathrm{ST}} \beta_{-l g}=\right.$ $\left.0.267 ; \mathrm{F}_{\mathrm{ST} G H}=0.030 ; \mathrm{F}_{\mathrm{ST} P R L}=0.071\right)$. The exact test for population differentiation indicated that gene distributions are significantly different among populations (exact $\mathrm{p}$ value of $\kappa$-cas $=0.002 \pm 0.002$; exact $\mathrm{p}$ value of $\alpha_{S I}$-cas $=$ $0.000 \pm 0.000$; exact $p$ value of $\beta$ - $l g=0.000 \pm 0.000$; exact $p$ value of $G H=0.002 \pm 0.001$; exact $\mathrm{p}$ value of $P R L=0.000$ $\pm 0.000)$.

As a whole, comparisons between pairs of population samples showed that seven out of fifteen estimated pairwise $\mathrm{F}_{\mathrm{ST}}$ for $\kappa$-cas exhibited significant differences between breeds, the $F_{\mathrm{ST}}$ values varying from 0.000 to 0.184 ; seven out of fifteen estimated pairwise $\mathrm{F}_{\mathrm{ST}}$ for $\alpha_{\mathrm{SI}}$-cas exhibited significant differences between breeds, the $\mathrm{F}_{\mathrm{ST}}$ values varying from 0.000 to 0.162 ; nine out of fifteen estimated pairwise $\mathrm{F}_{\mathrm{ST}}$ for $\beta$ - $\lg$ exhibited significant differences between breeds, the $\mathrm{F}_{\mathrm{ST}}$ values ranging from 0.000 to 0.252 ; six out fifteen estimated pairwise $\mathrm{F}_{\mathrm{ST}}$ for $G H$ exhibited significant differences between breeds, the $\mathrm{F}_{\mathrm{ST}}$ values varying from 0.000 to 0.609 ; five out of fifteen estimated pairwise $\mathrm{F}_{\mathrm{ST}}$ for $P R L$ exhibited significant differences between breeds, the $\mathrm{F}_{\mathrm{ST}}$ values varying from 0.000 to 0.112 .

\section{Discussion}

In the present report, the polymorphisms of five loci related to dairy production were characterized in six Creole cattle breeds from Argentina and Bolivia. The results are discussed focusing on their historical origin, recent differentiation and selection events, Zebu gene introgression, and population structure.

The variants of the analyzed loci are found in nearly all cattle breeds studied, presumably because they are very ancient polymorphisms. Therefore, it is the allelic distribution, rather than diagnostic alleles, that characterizes the differences between breeds or groups of breeds for these genes.

As a rule, for the loci studied, the same alleles were predominant across all six breeds. At the $\alpha_{S 1}$-cas locus, variant $\mathrm{B}$ was the most abundant in all studied populations. In addition, alleles $G H A$ and $P R L b$ were the most common variants, while the $\beta-L g$ variant $A$ had the highest allele frequencies in most of the Creole cattle breeds analyzed. On the other hand, at the $\kappa$-cas locus, variant $\mathrm{A}$ had the highest frequency in four out of six samples (Tables 1-5).

In a number of instances, a geographical cline in the frequencies of alleles, such as $\alpha_{S 1}-c a s, \kappa-c a s, G H$, serum albumin, several microsatellites and Y-chromosome polymorphisms, has been reported in bovine breeds. These gradients havebeen shown to be related to different causes, such as domestication center, population origin, migration route, gene introgression and/or adaptive effects of a particular allele (Baker and Manwell, 1980; Medjugorac et al., 1994; MacHugh et. al., 1994, 1997).

As mentioned earlier, American Creole cattle are pure descendants of the bovines introduced in America by the Spanish and Portuguese conquerors. Therefore, American and Iberian native breeds are expected to exhibit similar gene frequency profiles. In accordance with this assumption, comparisons between our results and the gene frequencies reported for Iberian native cattle breeds showed a concordance between the ranges of allelic frequencies of both groups of breeds.

Baker and Manwell (1980) described a cline for $\alpha_{S 1}$-cas $C$, ranging from Northern Europe to India. Among European cattle breeds, the highest gene frequencies of $\alpha_{S 1}$-cas $C$ were observed in the primigenius group of breeds, hat includes Iberian breeds, with gene frequency values varying between 0.2 and 0.4 (Baker and Manwell, 1980; Arranz Santos, 1994; Beja-Pereira et al., 2002). In agreement with these data, the gene frequencies calculated for the Creole cattle breeds studied (0.056-0.347) overlap with the Iberian distribution.

Locus $\kappa$-cas did not display a clear cline like the $\alpha_{S I}$-cas gene. This trend holds only for European breeds, allowing the differentiation of certain breed groups (Baker and Manwell, 1980). The Creole cattle breeds studied showed a wide range of $\kappa$-cas $A$ gene frequencies ( $0.355-$ $0.700)$, that overlapped with the data reported for the Iberian (0.470-0.762) and other South-American breeds (Arranz Santos, 1994; Arranz Santos et at., 1996; Postiglioni et at., 1998; Kemenes et al., 1999; Viana et al., 2001; Beja-Pereira et al., 2002; Lara et al., 2002).

At locus $\beta-L g$, variants $A$ and $B$ are usually found in all bovine breeds, the gene frequency of $\beta-L g B$ being higher than that of $\beta-\operatorname{Lg} A$. Nevertheless, this gene is a useful marker to differentiate certain breed groups, such as Lowland brachyceros versus Upland brachyceros (Baker and Manwell, 1980). The Creole cattle breeds studied showed a range of gene frequencies for $\beta-\operatorname{Lg} B(0.517-$ $0.825)$ that overlapped with the data reported for the Iberian (approximately 0.516-0.800) and other South-American breeds (Baker and Manwell, 1980; Arranz Santos, 1994; Arranz Santos et al., 1996; Kemenes et al., 1999).

At locus $G H$, the breed frequencies of allele $G H A$, as related to their geographical origin, show a low frequency for breeds stemming from Northern Europe, moderate frequencies for breeds from Eastern Europe or the countries surrounding the Mediterranean basin, and very high frequencies for breeds from the Indian subcontinent (Lagziel et al., 2000). The $G H A$ range of gene frequencies found in Argentine and Bolivian Creole (0.757-1.00), Iberian (0.396-0.955), and other South-American Creole cattle 
breeds were overlapping (Arranz Santos, 1994; Arranz Santos et al., 1996; Kemenes et al., 1999; Reis et al., 2001).

At locus $P R L$, variant $\mathrm{b}$ exhibited a gene frequency higher than 0.80 in all studied breeds, being fixed or nearly fixed in several Creole cattle populations. In concordance with these results, the PRL $b$ variant is also the most common allele in the Spanish Retinta breed (personal communications, $P R L b$ gene frequency $=0.80)$. Unfortunately, our results could not be compared with other breeds, because no other population data for this polymorphism were reported so far.

During the last century, American Creole cattle suffered a drastic reduction in population size, a significant subdivision into small and isolated herds, and gene introgression due to admixture mainly with Zebu breeds. The first factor that we considered here was gene introgression. At two out of five studied loci $\left(\alpha_{S^{-}}-c a s\right.$ and $\left.G H\right)$, Zebu breed gene frequencies are particularly different from those of taurine cattle breeds. Most Zebu breeds have a $\alpha_{S I^{-}}$-cas $C$ gene frequency of about 0.9 , whereas it is very unusual for European breeds to have a gene frequency above 0.5 for this variants, and it is usually around 0.1 or less in the North-European and Pied Lowland breeds. Besides, in Bos taurus, the GH locus was found to have two alleles, whereas it was monomorphic (allele L only) in Zebu breeds (Lagziel et al., 2000; Arranz Santos, 1994; Kemenes et al., 1999).

Taking into account that the $\alpha_{S I}$-cas $C$ and $G H A$ gene frequencies are higher in Zebu breeds than in taurine breeds, it was expected that an introgression of Zebu genes into the Creole cattle population would result in an increase of the frequency of these alleles. The genetic increase could be stronger, as the rate of mixing increased. However, our results do not support this hypothesis, since we found no relation between both variables. In this regard, the unmixed Argentine Creole and the Patagonian Creole cattle exhibited the highest $\alpha_{S I}$-cas $C$ and $G H A$ frequencies, respectively. In contrast, the Yacumeño breed, that exhibited 17\% of gene introgression (measured through Y-chromosome polymorphisms; Giovambattista et al., 2000), had the lowest gene frequencies for both variants.

Similarly unexpected results for the $G H$ locus were reported by Kemenes et al., (1999). These authors showed that, although the Santa Gertrudis breed is 5/8 European, it was found to be much closer to Zebu cattle than expected. These authors proposed that this similarity for the investigated marker might reflect selection for Zebu genes after formation of the breed. Nevertheless, the results observed

Table IV - Number of detected alleles ( $\left.\mathrm{n}_{\mathrm{a}}\right)$, gene frequencies, unbiased expected heterozygosity $\left(\mathrm{h}_{\mathrm{e}}\right)$ and its standard errors (SD), and $\mathrm{F}_{\text {IS }}$ index estimated for growth hormone locus in Argentine Creole ( $\mathrm{ACc}$ ), Patagonian Creole ( $\mathrm{PaCc})$, Saavedreño ( $\mathrm{SaCc}$ ), Chaqueño Boliviano (ChBCc), Yacumeño ( $\mathrm{YaCc}$ ), and Chusco (ChuCc) cattle breeds.

\begin{tabular}{lcccccc}
\hline Breed & $\mathrm{n}_{\mathrm{a}}$ & \multicolumn{3}{c}{ Allele frequency } & \multirow{2}{*}{$\mathrm{h}_{\mathrm{e}}$-SD } & $\mathrm{F}_{\text {IS }}$ - $\mathrm{p}$ value \\
\cline { 3 - 5 } & & $\mathrm{A}$ & $\mathrm{B}$ & $\mathrm{SD}$ & & \\
\hline $\mathrm{ACc}^{1}$ & 2 & 0.757 & 0.243 & 0.052 & $0.373 \pm 0.053$ & $0.000 ; 1.000^{2}$ \\
$\mathrm{PACc}$ & 1 & 1.000 & 0.000 & 0.000 & $0.000 \pm 0.000$ & $\mathrm{NC}$ \\
$\mathrm{SaCc}$ & 2 & 0,762 & 0,238 & 0.024 & $0.360 \pm 0.025$ & $0.168 ; 0.048$ \\
$\mathrm{ChBCc}$ & 2 & 0,855 & 0,145 & 0.045 & $0.252 \pm 0.064$ & $0.106 ; 0.491$ \\
$\mathrm{YaCc}$ & 2 & 0.700 & 0.300 & 0.065 & $0.429 \pm 0.053$ & $-0.219 ; 0.370$ \\
$\mathrm{ChuCc}$ & 2 & 0.909 & 0.091 & 0.063 & $0.173 \pm 0.101$ & $-0.053 ; 1.000$ \\
\hline
\end{tabular}

${ }^{1}$ Corresponding to an average of 8 ACc populations; ${ }^{2}$ Estimated by Fisher's exact test; NC: not calculated.

Table $\mathbf{V}$ - Number of detected alleles $\left(\mathrm{n}_{\mathrm{a}}\right)$, gene frequencies, unbiased expected heterozygosity $\left(\mathrm{h}_{\mathrm{e}}\right)$ and its standard errors (SD), and $\mathrm{F}_{\text {IS }}$ index estimated for the prolactin locus in Argentine Creole ( $\mathrm{ACc}$ ), Patagonian Creole ( $\mathrm{PaCc}$ ), Saavedreño ( $\mathrm{SaCc}$ ), Chaqueño Boliviano (ChBCc), Yacumeño ( $\mathrm{YaCc}$ ), and Chusco (ChuCc) cattle breeds.

\begin{tabular}{lcccccc}
\hline Breed & $\mathrm{n}_{\mathrm{a}}$ & \multicolumn{3}{c}{ Allele frequency } & \multirow{2}{*}{$\mathrm{H}_{\mathrm{e}} \pm \mathrm{SD}$} & $\mathrm{F}_{\text {IS }}$ - $\mathrm{p}$ value \\
\cline { 3 - 5 } & & $\mathrm{b}$ & $\mathrm{B}$ & $\mathrm{SD}$ & & \\
\hline $\mathrm{ACc}^{1}$ & 2 & 0.961 & 0.039 & 0.000 & $0.075 \pm 0.017$ & $0.000 ; 1.000^{2}$ \\
$\mathrm{PACc}$ & 2 & 0.950 & 0.050 & 0.028 & $0.096 \pm 0.013$ & $-0.036 ; 1.000$ \\
$\mathrm{SaCc}$ & 2 & 0.816 & 0.184 & 0.020 & $0.301 \pm 0.025$ & $-0.114 ; 0.1437$ \\
$\mathrm{ChBCc}$ & 2 & 0.983 & 0.017 & 0.017 & $0.034 \pm 0.033$ & $\mathrm{NC}$ \\
$\mathrm{YaCc}$ & 1 & 1.000 & 0.000 & 0.000 & $0.000 \pm 0.000$ & $\mathrm{NC}$ \\
$\mathrm{ChuCc}$ & 2 & 0.909 & 0.091 & 0.063 & $0.173 \pm 0.101$ & $-0.053 ; 1.000$ \\
\hline
\end{tabular}

${ }^{1}$ Corresponding to an average of 8 ACc populations; ${ }^{2}$ Estimated by Fisher's exact test; NC: not calculated. 
in the Creole cattle may be due to stochastic factors such as genetic drift and founder group effect.

The second factor discussed here is the effect of population structure on the gene frequency profile and the degree of genetic diversity within each population. The $\mathrm{F}_{\mathrm{ST}}$ and the exact test for genetic differentiation showed a significant subdivision of the Bolivian and Argentine Creole cattle population. This heterogeneous genetic pattern seems to be a major characteristic of American Creole breeds (Russell et al., 2000; Giovambattista et al., 2001) and could be the consequence of the subdivision of Creole cattle from this region into small herds, isolated or with a low degree of gene flow among them, and adapted to a wide range of environments. In concordance with this hypothesis, a lower level of average heterozygosity was observed in the Patagonian Creole cattle breed, which is the most isolated population.

As expected, both in Argentine Creole cattle populations and in Bolivian Creole cattle breeds, gene frequencies varied around average values. Within the same population, one variant was fixed or almost fixed. For example, $G H$ and $P R L$ were fixed in the Patagonian and Yacumeño Creole cattle, respectively (Tables 4 and 5). In addition, the studied populations showed differences among them regarding the $\mathrm{h}_{\mathrm{e}}$ of each locus, that result from variations in allele frequencies, rather than from the presence/absence of particular alleles. However, there were no significant differences regarding the $\mathrm{H}_{\mathrm{e}}$ at the analyzed loci, nor an increase of homozygous genotypes. No evidence of inbreeding was detected in any one of the studied populations.

In conclusion, the calculated gene frequencies of Argentine and Bolivian Creole cattle breeds were close to those of the Iberian breeds and other South-American Creole cattle that are historically related. On the other hand, although Zebu gene introgression has been reported, these breeds seem to be far from the Zebu gene frequency profiles. Furthermore, the Argentine and Bolivian Creole cattle showed significant levels of subdivision, but each population has nevertheless maintained its own degree of genetic variability.

\section{Acknowledgments}

We thank Lic. Laura Albino for her many helpful comments on the manuscript. This work was supported by grants from the Japan International Cooperation Agency (JICA), the National University of La Plata and the National Research Council (CONICET) and the Comisión de Investigaciones Científicas de la Provincia de Buenos Aires (CIC).

\section{References}

Agrawala PL, Wagner VA and Geldermann H (1992) Sex determination and milk protein genotyping of pre-implantation stage bovine embryos using multiplex PCR. Theriogenology 38:969-978.
Arranz Santos, JJ (1994) Estudio genético en poblaciones bovinas mediante polimorfismos bioquímicos y de DNA (Variaciones puntuales y microsatélites). Tesis doctoral de la Universidad de León, Facultad de Veterinaria, Departamento de Producción Animal I.

Arranz Santos JJ, Bayon Y and San Primitivo F (1996) Comparison of protein markers and microsatellites in differentiation of cattle populations. Animal Genetics 27:415-419.

Baker, ACM and Manwell, C (1980) Chemical classification of cattle. I. Breed groups. Animal Blood Groups Biochem. Genet. 11:127-150.

Beja-Pereira A, Erhardt G, Matos C, Gama L and Ferrand N (2002) Evidence for a geographical cline of casein haplotypes in Portuguese cattle breeds. Animal Genetics 33:295300.

David VA and Deutch AH (1992) Detection of S1-casein genomic variants using the allele-specific polymerase chain reaction. Animal Genetics 23:425-429.

Giovambattista G, Ripoli MV, De Luca JC, Mirol P, Lirón JP and Dulout FN (2000) Geographic distribution and frequency of taurine Bos taurus and zebu Bos indicus Y chromosome haplotypes amongst Argentine and Bolivian Creole cattle breeds. Animal Genetics 31:302-5.

Giovambattista G, Ripoli MV, Peral García P and Bouzat JL (2001) Indigenous domestic breeds as reservoirs of genetic diversity: The Argentine Creole Cattle. Animal Genetics $32: 240-247$

Gou SW and Thompson EA (1992) Performing the exact test of Hardy-Weinberg proportion for multiple alleles. Biometrics 48:361-372.

Kantanen J, Olsaker I, Holm LE, Lien S, Vilkki J, Brusgaard K, Eythorsdottir E, Danell B and Adalsteinsson S (2000) Genetic diversity and population structure of 20 North European cattle breeds. Journal of Heredity 91:446-457.

Kemenes PA, Correia de Almeida Regitano L, Jordão de Magalhães Rosa A, Parker IU, Razook AG, Andrade de Figuereido L, Silva NA, Etchegaray MAL and Lehman Coutino L (1999) א-casein, $\beta$-lactoglobulin and growth hormone allele frequencies and genetic distances in Nelore, Gyr, Guzera, Caracacu, Charolais, Canchim and Santa Gertrudis cattle. Genetics and Molecular Biology 22:539-541.

Lagziel A, DeNise S, Hanotte O, Dhara S, Glazko V, Broadhead A, Davoli R, Russo V and Soller M (2000) Geographical and breed distribution of an Msp I PCR-RFLP in the bovine growth hormone (bGH) gene. Animal Genetics 31:210-213.

Lara MAC, Gama LT, Bufarah G, Sereno JRB, Celegato EML and de Abreu UP (2002) Genetic polymorphisms at the $\kappa$-casein locus in Pantanereiro cattle. Archivos de Zootécnia 51:99-105.

Lewin HA, Schmitt K, Hubert R, Van Eijk MJT and Arnheim N (1992) Close linkage between bovine prolactin and BoLADRB3 genes: Genetics mapping in cattle by single sperm typing. Genomics 13:44-48.

Loftus RT, Ertugrul O, Harba AH, El-Barody MA, MacHugh DE, Park SD and Bradley DG (1999) A microsatellite survey of cattle from a centre of origin: the Near East. Molecular Ecology 8:2015-2022.

MacHugh DE, Loftus RT, Bradley DG, Sharp PM and Cunningham P (1994) Microsatellite DNA variation within and among European cattle breeds. Proceedings of the Royal Society of London 256:25-31. 
MacHugh DE, Shriver MD, Loftus RT, Cunningham P and Bradley DG (1997) Microsatellite DNA variation and the evolution, domestication and phylogeography of Taurine and Zebu cattle (Bos taurus and Bos indicus). Genetics 146:1071-1086.

Manwell C and Baker MA (1980) Chemical classification of cattle. 2. Phylogenetic tree and specific status of the Zebu. Animal Blood Groups Biochemistry. Genet 11:151-162.

Medjugorac I, Kustermann W, Lazar P, Russ I and Pirchner F (1994) Marker-derived phylogeny of European cattle supports demic expansion of agriculture. Animal Genetics 25:19-27.

Medrano JF and Aguilar-Cordoba E (1990) Polymerase chain reaction amplification of bovine $\beta$-lactoglobulin genomic sequences and identification of genetic variants by RFLP analysis. Biotechnology 1:73-77.

Moazami-Goudarzi K, Laloe D, Furet JP and Grosclaude F (1997). Analysis of genetic relationships between 10 cattle breeds with 17 microsatellites. Animal Genetics 28:338345 .

Nei M (1987) Molecular evolutionary genetics. Columbia University Press. New York. p 512.

Postiglioni A, Rincón G, Kelly L, DAngelo M, Gagliardi R and De Andrés Cara D (1998) Caracterización Genética de los Bovinos Criollos del Uruguay. II Estudio de su Variabilidad Genética. Archivos de Zootecnia 47:225-231.
Primo AT (1992) El ganado bovino ibérico en las Américas 500 años después. Archivos de Zootecnia 41:421-432.

Raymond M and Rousset F (1995) GENEPOP (version 1.2): A population genetics software for exact test and ecumenicism. Journal of Heredity 86:248-249.

Reis C, Navas D, Pereira M and Cravador A (2001) Growth hormone ALUI polymorphism analysis in eight Portuguese bovine breeds. Archivos de Zootecnia 50:41-48.

Russell ND, Rios J, Erosa G, Remmenga MD and Hawkins DE (2000) Genetic differentiation among geographically isolated populations of Criollo cattle and their divergence from other Bos taurus breeds. Journal of Animal Science 78:2314-2322.

Schneider S, Roessli D and Excoffier L (2000) ARLEQUIN a software for population genetics data analysis version 2.000. University of Geneva, Geneva, Switzerland.

Viana, JL, Fernández A, Iglesias A, Sánchez L and Becerra J (2001) Análisis de los genotipos más frecuentes de la K-caseína en la raza vacuna Rubia Gallega mediante PCR/ RFLPs. Archivos de Zootecnia 50:91-96.

Weir BS and Cockerham CC (1984) Estimating F-statistics for the analysis of populations structure. Evolution 38:1358-1370.

Wilkins JV, Martinez L and Rojas F (1982) El Ganado Vacuno Criollo. CIAT. Santa Cruz (Bolivia). Documento 31.

Yao J, Aggrey SE, Zadworny D, Hayes JF and Kuhnlein U (1996) Sequence variations in the bovine growth hormone gene characterized by single-strand conformation polymorphism (SSCP) analysis and their association with milk production traits in Holsteins. Genetics 144:1809-1816. 